\title{
Pengembangan Produk Wisata Berbasis Kharakteristik Wisatawan Prancis di PT. Karang Bali Asli (KBA) Tur Denpasar
}

\author{
Ni Luh Putu Superyadi (superyadi92@gmail.com), \\ I Wayan Wiwin (wiwinkayoan@gmail.com), \\ I Gusti Ngurah Pertu Agung (pertuagung04@gmail.com) \\ Jurusan Pariwisata Budaya, Fakultas Dharma Duta, IHDN Denpasar
}

\begin{abstract}
Based on the data from the Bali Provincial Tourism Office in 2018, the number of French tourist visits to Bali continues to increase every year, even in 2018 it occupies the seventh position from the top ten suppliers of tourists to Bali. This condition is inseparable from the role of the Travel Agency in Bali, which always innovates and develops tourism products that suit the needs and characteristics of tourists. One of the Travel Agencies that focuses on working on the French tourist market is PT. Karang Bali Asli (KBA) Tour Denpasar which has been operating since 1999. This study examines three problems, namely: (1) What are the tourist characteristics-based products of French tourists offered by PT. KBA Tour ?; (2) What is the perception of French tourists on tourism products offered by PT. KBA Tour ?; and (3) How is the development of tourism products based on the characteristics of French tourists at PT. KBA Tour? This research is a qualitative research, with methods of collecting data through observation, in-depth interviews, questionnaires, and literature studies. The theory used was the Marketing Mix Theory and Perception Theory. The results of the study show that: (1) In general, tourism products offered by PT. KBA Tour Denpasar are interactive tourism products or tourism products that create intractions between tourists with the local community, as well as tourism products that create interaction between tourists and the natural environment; (2) The perception of French tourists on tourism products offered by PT. KBA Tur, shows positive (good) values for the four indicators in the Marketing Mix theory, namely: Product, Price, Place, and Promotion; (3) Business development of tourism products based on the characteristics of French tourists at PT. KBA Tur can be carried out as expected because of the synergy and support of the local community, company employees, and feedback and input from the tourists themselves, so that the tourism products offered by PT. KBA Tur are very popular with tourists and can be sustainable.
\end{abstract}

Keywords: Development, Tourism Products, Tourist Characteristics.

\section{Pendahuluan}

Indonesia sebagai salah satu Negara yang memiliki potensi sumber daya alam dan budaya yang sangat besar terus berupaya untuk mengembangkan industri pariwisata sebagai industri jasa unggulan, karena telah terbukti mampu menghasilkan devisa Negara dan menciptakan banyak lapangan pekerjaan, sehingga sangat berdampak bagi pertumbuhan perekonomian Negara.

Bali sebagai salah satu andalan destinasi pariwisata Indonesia tidak pernah surut dalam melakukan inovasi dan deversifikasi produk wisata sehingga mampu menarik minat wisatawan untuk berkunjung. Tidak mengherankan jika Bali untuk ke-13 kalinya kembali meraih penghargaan internasional sebagai The Best Island in Asia Pacific versi DestinAsian Magazine Readers' Choice Awards 2018. Terpilihnya Bali bukan tanpa sebab, Pulau Dewata memiliki 
daya tarik wisata yang sangat lengkap. Destinasi alam, budaya, sejarah, maupun buatan manusia, semuanya ada di Bali. Dengan segala pesonanya, pada 2017 Bali juga meraih The Best Destination in The World 2017 oleh TripAdvisor. Berdasarkan data statistik Dinas Pariwisata Provinsi Bali, jumlah kunjungan wisatawan mancanegara ke Bali pada tahun 2018 mencapai 6.070.473 orang, sehingga melampau target enam juta wisatawan.

Keberhasilan Bali meraih semua predikat tersebut tidak terlepas dari peran semua stakeholder pariwisata yang terlibat, salah satunya adalah peran Biro Perjalanan Wisata. Biro Perjalanan Wisata (BPW) adalah perusahaan yang bersifat komersial yang mengatur, dan menyediakan pelayanan bagi seseorang ataupun sekelompok orang untuk melakukan perjalanan dengan tujuan utama berwisata. Biro Perjalanan Wisata (BPW) juga berperan sebagai penghubung wisatawan dengan berbagai penyedia jasa dalam bidang industri pariwisata lainnya, seperti: transportasi, akomodasi, restoran dan pihak pengelolaan daya tarik wisata. Biro Perjalanan Wisata (BPW) berada dibawah naungan ASITA (Association of The Indonesian Tours and Travel Agencies) yang merupakan swebuah asosiasi yang mewadahi pengusaha atau pelaku usaha di bidang jasa perjalanan wisata di Indonesia,.

PT. Karang Bali Asli Tur Denpasar atau yang kemudian dikenal dengan nama KBA Tur merupakan salah satu dari Biro Perjalanan Wisata (BPW) yang beroperasi di Bali yang didirikan oleh I Putu Winastra, S.Sos. pada tanggal 12 Juli 1999. KBA Tur adalah sebuah perusahaan yang bergerak dalam bidang jasa perjalanan wisata dengan tujuan untuk memperkenalkan keanekaragaman kekayaan alam dan budaya di kepulauan nusantara kepada wisatawan. Adapun paket wisata yang ditawarkan berupa FIT (Free Independent Travellers), GIT (Group Inclusive Tour), pemesanan akomodasi, pemesanan tiket pesawat terbang, paket wisata MICE (Meeting, Incentive, Convention, Exhibition), penyediaan pelayanan pramuwisata (tour guide), serta pelayanan jasa transportasi wisata. (kbatur.com, 2018).

KBA Tur Denpasar merupakan salah satu Biro Perjalanan Wisata di Bali yang segmen pasarnya adalah wisatawan Perancis, dimana pangsa pasar wisatawan Perancis saat ini sedang berkembang pesat dan setiap tahun terus mengalami peningkatan. Untuk itu, dipandang perlu melakukan penelitian terkait dengan pengembangan produk wisata berbasis wisatawan Perancis ini. Adapun permasalahan yang dikaji dalam penelitian ini adalah sebagai berikut; (1) Apa saja produk wisata berbasis karakteristik wisatawan Perancis yang ditawarkan oleh PT. KBA Tur?; (2) Bagaimana persepsi wisatawan Perancis terhadap produk wisata yang ditawarkan oleh PT. KBA Tur?; dan (3) Bagaimana pengembangan produk wisata berbasis karakteristik wisatawan Perancis di PT. KBA Tur?.

\section{Pembahasan}

Produk Industri Pariwisata merupakan raw materials (bahan buku) bagi perusahaan Biro Perjalanan Wisata (BPW) selaku tour operator (perencana dan penyelenggara perjalanan wisata ) untuk menyusun tour package (paket wisata) yang selanjutnya ditawarkan atau dipasarkan kepada calon wisatawan. Produk final dari industri pariwisata tidak lain adalah kumpulan dari bermacam-macam produk yang dihasilkan oleh perusahaan-perusahaan yang memberi pelayanan langsung kepada wisatawan saat melakukan perjalanan wisata (Yoeti, 2003).

Produk pariwisata adalah suatu bentukan yang nyata dan tidak nyata, dalam suatu kesatuan rangkaian perjalanan yang hanya dapat dinikmati apabila seluruh rangkaian perjalanan tersebut dapat memberikan pengalaman yang baik dan memuaskan bagi yang melakukan perjalanan. Produk pariwisata merupakan produk yang nyata dan tidak nyata yang merupakan rangkaian produk barang dan jasa yang tidak hanya mempunyai sifat ekonomis, namun juga bersifat sosial dan psikologis. Produk pariwisata merupakan berbagai jenis jasa dimana satu dengan lainnya saling terkait yang dihasilkan oleh berbagai usaha pariwisata, misalnya: usaha perjalanan wisata, penyedia akomodasi, transportasi wisata, jasa makanan dan 
minuman, daya tarik wisata, penyelenggara kegiatan hiburan dan rekreasi serta perusahaan lain yang terkait (Muljadi \& Warman, 2014).

Karakteristik wisatawan menurut Pitana \& Gayatri (2005: 74) mengemukakan bahwa karakteristik wisatawan meliputi: (a) Usia; (b) Jenis kelamin; (c) Profesi atau pekerjaan; (d) Cara mendapatkan informasi; dan (e) Motivasi perjalanan. Menurut Seaton dan Bennet (dalam Tenouye, 2016:16) karakteristik wisatawan biasanya dibedakan berdasarkan karakteristik perjalanannya (trip descriptor) dan karakteristik wisatawannya (tourist descriptor). Karakteristik Trip Descriptor, yaitu karakteristik wisatawan berdasarkan jenis perjalanan yang dilakukannya. Secara umum jenis perjalanan dapat dibedakan menjadi: perjalanan rekreasi, mengunjungi teman atau keluarga (visiting friends and relative), perjalanan bisnis dan kelompok perjalanan lainnya. Sedangkan, karakteristik Tourist Descriptor, yaitu karaktersitik wisatawan berdasarkan: (1) Sosio-demografis (usia, jenis kelamin, tingkat pendidikan, pekerjaan, tingkat pendapatan, status perkawinan); (2) Geografis (lokasi tempat tinggal, Negara asal); dan (3) Psikografis (kelas sosial, life-style dan karakteristik personal).

Jenis penelitian ini merupakan penelitian kualitatif dengan teknik pengumpulan data menggunakan teknik observasi, wawancara mendalam, kuesioner, dan studi kepustakaan. Informan dalam penelitian ini diperoleh dengan teknik purposif, sedangkan responden wisatawan diperoleh dengan teknik accidental sampling yang dilakukan pada bulan September sampai dengan Desember 2018. Teknik Analisis data menggunakan analisis deskriptif kualitatif dan khusus dalam menganalisis persepsi wisatawan digunakan alat analisis berupa skala likert.

PT. Karang Bali Asli (KBA) Tur Denpasar adalah salah satu Biro Perjalanan Wisata di Bali yang sangat fokus menggarap segmen pasar wisatawan Perancis. PT. KBA Tur Denpasar menyediakan layanan produk wisata berupa :

1. Hotel Voucher Domestik dan Internasional

Dengan adanya anak perusahaan dibawah naungan PT. KBA Tur yaitu Vokamo, sebuah perusahaan dibidang reservasi yang menyediakan jasa pemesanan/reservasi voucher hotel baik domestik maupun internasional.

2. Individual \& Group Traveller

Individual Traveller yang dikenal dengan nama FIT merupakan wisatawan yang melakukan perjalanan wisata secara individual dengan menggunakan jasa ataupun paket wisata dari PT. KBA Tur Denpasar. Group Traveller yang lebih dikenal dengan nama GIT merupakan sekelompok wisatawan atau rombongan yang melakukan perjalanan wisata menggunakan jasa dari PT. KBA Tur Denpasar. Untuk harga yang ditawarkan oleh PT. KBA Tur bersifat relatif, karena harga yang ditentukan sesuai dengan aktifitas maupun paket wisata yang diminati oleh wisatawan.

3. MICE (Meeting, Incentive, Convention, Exhibition)

Merupakan perpaduan antara perjalanan wisata dan rangkaian kegiatan pertemuan, event, kongres, atau acara pameran oleh sekelompok orang atau organisasi baik swasta maupun pemerintah. PT. KBA Tur Denpasar juga memiliki produk yang menunjang kegiatan MICE seperti penyediaan akomodasi, transportasi dan penyediaan tempat pelaksanaan MICE yang mampu bersaing di pasar internasional. Begitu juga dengan produk MICE yang ditawarkan oleh PT. KBA Tur Denpasar, penetapan harga yang diberikan juga bersifat relatif dikarenakan permintaan, kebutuhan dan fasilitas yang berbeda-beda yang disesuaikan oleh keinginan customer dalam penyelenggaraan event tersebut.

4. Golf Package

Produk wisata yang dimiliki oleh PT. KBA Tur Denpasar yang menyediakan fasilitas permaianan golf dikombinasikan dengan berwisata ke beberapa daya tarik wisata yang ada di Bali.

5. Wedding Package 
Merupakan sebuah paket yang menawarkan penyediaan sebuah acara pernikahan/wedding. Dimana segala penyediaan dan pengadaan persiapan mulai dari tempat/venue, akomodasi, kostum dan restoran disiapkan oleh PT. KBA Tur Denpasar. Harga yang ditawarkan juga bervariasi, dikarenakan adanya penyesuaian dengan permintaan costumer.

6. Adventure

Produk ini yang merupakan produk unggulan yang banyak diminati oleh wisatawan Eropa terutama wisatawan Perancis. Produk ini merupakan perpaduan antara wisata alam seperti Rainforest trakking, volcano climbing, cycling, snorkeling, diving yang dipadukan dengan wisata budaya yang ada.

7. Ticketing Services untuk penerbangan domestik \& internasional

Ticketing sendiri merupakan produk yang dimiliki oleh Vokamo yang merupakan anak perusahaan dari PT. Karang Bali Asli Tur Denpasar. Melayani pemesanan tiket penerbangan domestik maupun internasional.

8. Car Rental Limousine

Penyediaan transportasi berupa mobil mewah Limousine yang disewakan dengan sistem sewa harian maupun sewa per-jam sesuai permintaan dari customer.

9. Cruise

Merupakan suatu produk yang berupa paket wisata yang menyuguhkan aktifitas hiburan di atas kapal cruise yang dipadukan dengan kegiatan bersantai/relaxing. Paket wisata cruise yang dimiliki oleh PT. KBA Tur Denpasar dibedakan menjadi dua yaitu Sunset Diner Cruise dan Lembongan Day Cruise.

Selain itu, PT. KBA Tur juga memiliki anak perusahaan yang bernama Karang Mesari Transport yang bergerak dalam bidang penyediaan armada transportasi pariwisata berupa armada Bus, ELF, Toyota Innova, APV, Toyota Commuter, Toyota Fortuner, dan Toyota Alphard. PT. KBA Tur juga telah memiliki usaha akomodasi wisata dengan nama D’Umah Bali dan De Klumpu Bali yang terletak di Desa Undisan Kabupaten Bangli yang dibangun dengan konsep ramah lingkungan yang merupakan suatu gagasan dalam penerapan EcoTourism.

PT KBA Tur sangat fokus dalam menggarap pasar wisatawan Perancis, dimana wisatawan Perancis yang berkunjung ke Bali pada umumnya berkeinginan untuk melakukan perjalanan wisata dengan interaksi dengan masyarakat lokal sekaligus mengenal budaya yang dalam bentuk wisata pedesaan (village tour), serta wisata alam berupa wisata adventure, wisata diving, snorkling, dan wisata pantai.

Adapun produk wisata berbasis karakteristik wisatawan Perancis yang ditawarkan oleh PT. KBA Tur adalah produk wisata dengan karakter yang secara umum memiliki sifat mendetail, sifat rasa ingin tahu yang tinggi, sifat keinginan wisatawan untuk berinteraksi langsung dengan masyarakat lokal serta memiliki ketertarikan terhadap budaya lokal. Wisatawan Perancis termasuk golongan wisatawan pecinta alam dan peduli akan kebersihan lingkungan.

Persepsi wisatawan Perancis terhadap produk wisata yang ditawarkan oleh PT. KBA Tur Denpasar dibedakan ke dalam empat indikator sesuai teori Bauran Pemasaran, yaitu Product, Place, Price, and Promotion. Ke-empat indikator tersebut dinilai berdasarkan karakteristik wisatawan Perancis yang diklasifikasikan menjadi lima karakteristik, yaitu: (1) Berdasarkan usia wisatawan, wisatawan dengan rentang usia 47-59 tahun adalah wisatawan yang terbanyak berkunjung yaitu dengan persentase $47 \%$ dan yang terendah adalah wisatawan dengan rentang usia $\geq 60$ tahun yaitu dengan persentase 9\%; (2) Berdasarkan jenis kelamin, wisatawan yang membeli paket wisata di PT. KBA Tur berjenis kelamin laki-laki jumlahnya seimbang dengan wisatawan berjenis kelamin perempuan; (3) Berdasarkan profesi, jumlah wisatawan yang berprofesi sebagai karyawan/karyawati di sebuah Travel Agent merupakan 
jumlah wisatawan tertinggi dengan persentase 28\%; (4). Berdasarkan cara mendapatkan informasi, wisatawan yang melakukan kunjungan dan menggunakan jasa PT. KBA Tur Denpasar sebanyak 50\% wisatawan mendapatkan informasi dari Travel Agent; (5) Motivasi wisatawan Perancis ke Bali didasari oleh adanya motivasi intrinsik atau motivasi yang timbul dari dalam diri wisatawan itu sendiri dengan persentase sebanyak $78 \%$.

Pengembangan produk wisata berbasis karakteristik wisatawan Perancis di PT. KBA Tur Denpasar dilakukan dengan meningkatkan sumber daya manusia di lingkungan perusahaan, serta menjalin kerja sama dengan berbagai pihak terutama masyarakat lokal selaku subyek yang akan melakukan interaksi langsung dengan wisatawan. Selain itu, PT. KBA Tur Denpasar juga menjalin kerjasama dengan beberapa perusahaan Travel Agent yang ada di Perancis. Untuk dapat senantiasa memberikan pelayanan yang terbaik dan memenuhi harapan wisatawan, pihak PT. KBA Tur Denpasar juga menggali informasi dan saran dari wisatawan yang telah menikmati layanan wisata di PT. KBA Tur sebagai bahan pertimbangan dalam melakukan perbaikan dan inovasi terhadap setiap produk wisata yang ditawarkan.

\section{Kesimpulan}

Berdasarkan hasil pembahasan di atas, maka dapat dikemukakan beberapa saran kepada PT. Karang Bali Asli Tur Denpasar dalam mengoptimalkan pengembangan produk wisata berbasis karakteristik wisatawan Perancis agar terciptanya sebuah produk wisata yang mampu bersaing di pasar internasional sehingga terjaga keberlanjutannya di masa depan. Adapun saran-saran yang disampikan adalah sebagai berikut:

1. Kepada pihak manajemen perusahaan sebagai penyedia produk wisata agar lebih dapat bersinergi dengan masyarakat lokal dalam menjaga kebersihan lingkungan terutama masalah sampah plastik. Mengingat kepekaan wisatawan Perancis terhadap kebersihan dan sanitasi lingkungan.

2. Untuk meningkatkan kepuasan wisatawan, diharapakan kepada pihak manajemen PT. KBA Tur Denpasar agar terus melakukan inovasi dan menyediakan produk wisata yang variatif, sehingga wisatawan memiliki banyak pilihan produk wisata sesuai dengan karakteristik dan harapannya.

3. Dalam menjaga kualitas produk, diharapakan kepada pihak manajemen PT. KBA Tur Denpasar untuk secara rutin melakukan inspection ke lapangan sebagai bagian dari quality control terhadap setiap produk wisata yang dipasarkan.

\section{Daftar Pustaka}

Damanik, Janianton, 2013. Pariwisata Indonesia (Antara Peluang Dan Tantangan). Yogyakarta: Pustaka Pelajar.

Delaunay, Bénédicte. 2012. Bescherelle La Conjugaison Pour Tous. Paris: Hatier.

Desky, M.A. 2001. Pengantar Bisnis Biro Perjalanan Wisata. Yogyakarta: Adicita Karya Nusa.

Gulo, W. 2002. Metodologi Penelitian. Jakarta: PT. Grasindo.

Kevin, Erick. 2016. Strategi Pemasaran Paket Wisata di Bali Easy Holiday Denpasar Bali. (Skripsi). Denpasar: Fakultas Pariwisata Universitas Udayana.

Koentjaraningrat. 1990. Pengantar Ilmu Antropologi. Jakarta: Rineka Cipta.

Kotler, Philip. 1997. Manajemen Pemasaran Analisis Perencanaan, Implementasi dan Pengendalian. Jakarta: Salemba Empat. 
Kotler, Philip and Gery Armstrong. 2012. Prinsip-Prinsip Pemasaran Jilid 1 Edisi 13. Jakarta: Erlangga.

Kreitner, Robert dan Angelo Kinicki. 2014. Prilaku Organisasi. Edisi 9. Buku 1. Jakarta: Salemba Empat.

Labrousse, Pierre. 2010. Kamus Indonesia-Perancis. Jakarta: Gramedia Pustaka Utama.

Le Moullec, Marc. 1995. Konjugasi Verba Perancis. Bandung: Centre Culturel Français de Bandung.

Lesot, Adeline. 2013. Bescherelle L’Essentiel. Paris: Hatier.

Muljadi, A.J. 2014. Kepariwisataan dan Perjalanan. Depok: PT. Rajagrafindo Persada.

Nurita, SE. 2014. Perencanaan dan Pelaksanaan Perjalanan Wisata Konsep dan Aplikasi. Bandung: Alfabeta.

Parangin, Erick Kevin. 2016. Strategi Pemasaran Paket Wisata di Bali Easy Holiday Denpasar Bali. (Skripsi). Denapasar: Fakultas Pariwisata Universitas Udayana.

Pitana, I Gde. 2005. Sosiologi Pariwisata. Yogyakarta: Andi Publisher.

Purnomo, Cahya. 2009. Strategi Pemasaran Produk Wisata Minat Khusus Goa Cerme Imogiri Bantul. Jurnal Karisma Vol. 3 No. 2, Hal. 99-112.

Rangkuti, Freddy. 2003. Measuring Customer Satisfaction: Gaining Customer Relationship Strategy. Jakarta: PT. Gramedia Pustaka Utama.

Resmayasari, Ira. 2012. Persepsi Wisatawan Perancis Terhadap "The Island Of Paradise". Jurnal Ilmiah Pariwisata, Vol. 2 No. 1, Hal. 109-222. Denpasar: Universitas Udayana.

Salomon, Michael R. 2004. Consumer Behavior, Buying, Having and Being. New Jersey: Prentice Hall.

Satit, Rezky Purna, Tat, Huam Hon, Rasli, Arman, Chin, Thoo Ai, Sukati, Indra. 2012. The Relationship Between Marketing Mix And Customer Decision Making Over Travel Agents: An Emperical Study: International Journal of Academic Research in Business and Social Science. Volume 2, No. 6, pp. 522-530.

Sugiyono. 2005. Memahami Penelitian Kualitatif. Bandung: Alfabeta.

Tenouye, Pius. 2016. Karakteristik, Motivasi dan Kepuasan Wisatawan Nusantara Yang Berkunjung Ke Daya Tarik Wisata City Tour Denpasar. (Skripsi). Denpasar: Fakultas Pariwisata Universitas Udayana.

Walgito, Bimo. 1990. Pengantar Psikologi Umum. Yogyakarta: Andi Offset.

Yoeti, Oka A. 2003. Tour and Travel Marketing. Jakarta: Pradnya Paramita.

Website :

http://www.disparda.baliprov.go.id diakses tanggal 12 Januari 2019. 
http://www.kbatur.com diakses tanggal 12 Januari 2019. 